\title{
Return Migration from Sweden to Finland
}

\author{
JOUNI KORKIASAARI
}

\section{Introduction}

This presentation is based on my study "Returnees from Sweden to Finland in 1980-81» made in the Institute of Migration in Turku (Korkiasaari 1983). The study was financed by the Ministry of Labor and the Department of Housing. The purpose of the study was to examine questions dealing with the nature of return migration and the problems of the returnees, especially insofar as factors incidental to work, financial stability and housing were concerned. The study was primarily based on information obtained from the questionnaires mailed to the returnees themselves.

In this paper I will mainly examine the theoretical aspects of return migration and some empirical results of my study mentioned above.

\section{The approach to migration research}

Migration can be examined from the point of wiev of society, region and individual. On the societal level, the focus is on the relationship between total socio-historical development and migration. Empirically then, this relationship can be clarified primarily through a statistical analysis of migration in relation to the development of society's economic activities, economic structure and population history.

On the regional level, the focus is on the development of various segments of society and related factors. In this case, primary causes are factors that affect the regional placement of production and the related mobility of the labor force. Thus migration is considered to be virtually inseparable from the mobility of the labor force; i.e., the result of changes taking place in economic structure and the attendant regional differentiation and transfer of jobs. The causes of migration are thus seen primarily in differences in regional opportunities.

On an individual level, migration is examined from the point of wiew of an individual's ability to satisfy his needs and the resultant behavioral processes. Individual, subjective motives for behavior are thus the causes of migration.

\section{Theoretical approach to return migration}

\section{Structural approach}

It is obvious from the foregoing that it is necessary to examine the causes of migration on a regional and social level in addition to an individual level. The two former levels deal with the structural causes of migration, i.e., the opportunities that different regions and societies are able to offer an individual in order to satisfy his needs. The individual level, on the other hand, deals with the needs and the resources that are available for their satisfaction. The resources of an individual determine the extent to which he is able to take advantage of opportunities in his environment. 
The opportunities in an environment can be divided into three primary areas, which have to do with the satisfaction of an individual's material, social and self-fulfilment needs. The central structural indicators, as far as material opportunities are concerned, might be the employment situation, salary level and housing situation in a country and a region. Factors indicative of social opportunities in the environment are the language and the culture of the region, and, in terms of an individual, friendship and family relations. Opportunities in terms of self-fulfilment are opportunities for education and hobbies.

\section{The causes and preconditions of return migration}

It was noted during the last century that a migratory flow is always followed by a countercurrent, i.e., return migration was seen as a natural result of earlier emigration. The statistics do indicate that increased return migration follows increased emigration after an interval of several years. Although earlier emigration thus explains return migration, it does not specifically explain why people return.

The structural causes and preconditions for return migration are related to the same factors as for emigration, i.e., to opportunities for economic, social and self-fulfilment in the regions of departure and arrival. It can be supposed that an emigrant generally "gains" financially when moving to a foreign country, but "loses" in other aspects. Thus it is understandable that the central factors in return migration are those where losses have experienced (in the area of social and self-fulfilment needs). Financial (material) factors have no significance as long as the differences between the country of departure and arrival do not change. If the differences substantially diminish or are reversed, financial considerations also increase in significance.

The strength and direction of migration between Sweden and Finland seems to be dependent on the Swedish labor market to the extent that an improving employment situation in Sweden indicates migration gains in Sweden's favor, and, correspondingly a weakening employment situation increases return migration to Finland. This seems to happen regardless of the employment situation in Finland. This conclusion is generally based on the figure illustrating the quantitative development of migratory flows and job openings as well as the unemployed in both countries. For return migration, the following graph could be drawn (see p. 139).

Information provided by the graph is not completely self-explanatory. Moreover, it must be noted that the interpretation is also influenced by the design of the graph (compare, for example, Komiteanmietintö 1982: 14, appendix 5; Työvoimakatsaus 1982,22 ).

The graph can be interpreted to mean, for example, that return migration is dependent on job openings in Finland (years 1969-71 and 1978). It also supports the proposition that return migration increases when job openings in Sweden decrease, although this interpretation is not totally unambiguous as far as years $1975-80$ are concerned. One of the difficulties in analyzing the graphs is the great emigration wave in the early 1970's and the resultant strong return migration, which can be interpreted as a natural" consequence of the great emigration wave and not so decisively dependent on the employment situation in the two countries.

In his studies, Hietala (1980) has attempted to explain the macroeconomic causes of migration through mathematical models, or so-called migration functions. In his return migration function, he considered job openings in Finland, unemployment in Sweden and differences in the salary levels between the countries. Moreover, he noted that return migration was dependent on the earlier emigration. Hietala concluded that job openings in Finland had the greatest 
F i g u r e 1. Migrants from Sweden to Finland, job openings in Finland and Sweden, and unemployed job seekers in Sweden from 1962-81

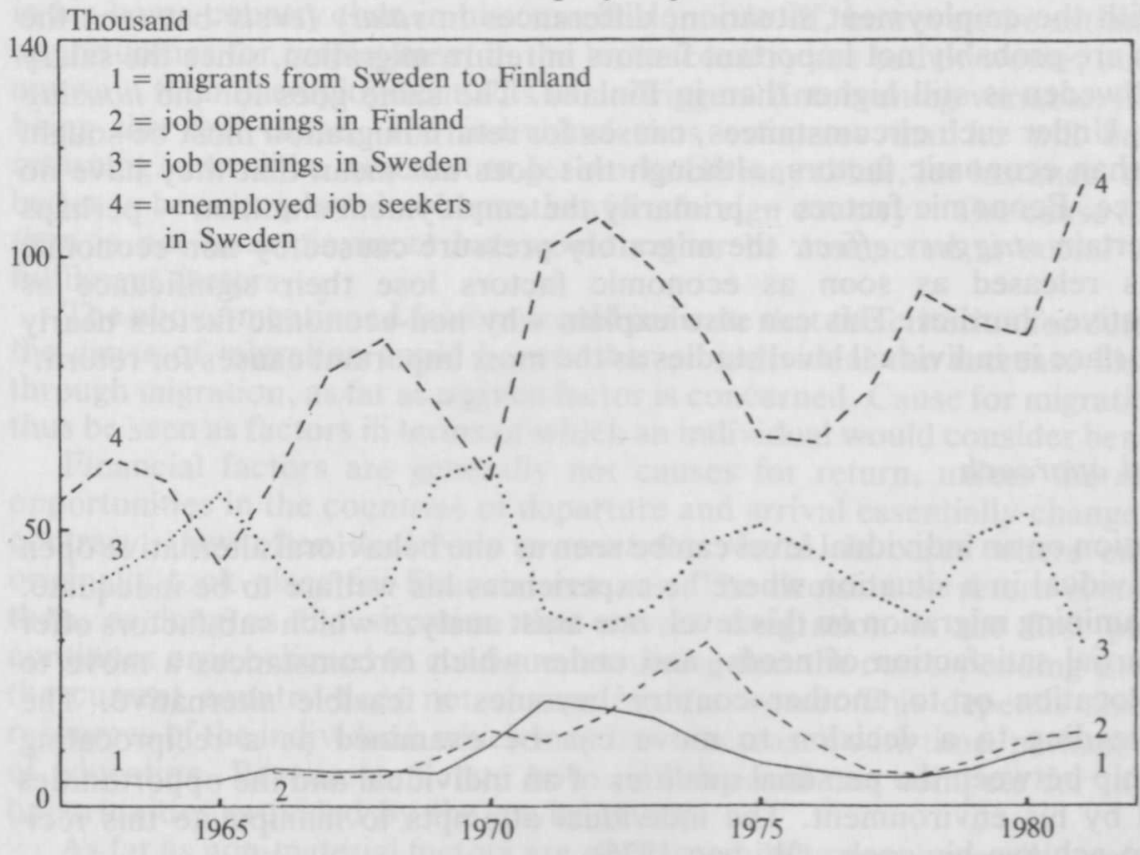

causative effect, one-and-a-half times as great as unemployment in Sweden. However, the effect of the employment situation on return migration is only half of that on emigration. Moreover, return migration depends greatly on earlier emigration.

It can be presumed that the unemployment problems that have lately increased in Sweden are one reason for increased return migration, particularly since these problems are concentrated in the fields that have traditionally employed most Finns. The economic boom of 1979-80 in Finland also increased the opportunities for return, at least temporarily. At the same time, the Swedish media presented a very positive image of Finland's economic development, and that was likely to increase willingness to return.

The economic boom in Finland was short-lived, however. Moreover, even at their lowest, the unemployment figures were very high, although the number of openings actually increased. While unemployment in Sweden has been at $2-3 \%$ level, in Finland it has fluctuated between 4.5-7.5\%. It must be noted, however, that one reason for the low unemployment figures in Sweden has been extensive government action to keep unemployment in check, and these measures have affected nearly the same number of people as have been unemployed. The degree of unemployment among the immigrants has, furthermore, been twice that of the native population. The developments in the employment situation in Finland constitute one reason for the strong return migration that continued in early 1982 , but then subsided somewhat later in the year when compared to the previous year. On the other hand, emigration to Sweden had decreased even more.

Since the employment situation is poor in both countries, the economic preconditions for migration in either direction are very poor. In other words, the effects of Finland's and Sweden's employment situation cancel out each other, so to speak. As such, the employment situation in the country of residence "pushes one to move, but at the same time the employment situation in the receiving country "prevents" the move. Thus, for example, it does not pay for an unemployed person residing in Sweden to return to Finland for financial reasons, 
unless he has a firm job available. Desire to return can further be dampened by the fact that unemployment benefits are better in Sweden than in Finland.

As with the employment situation, differences in salary levels between the countries are probably not important factors in return migration, since the salary level in Sweden is still higher than in Finland. The same goes for the housing situation. Under such circumstances, causes for return migration must be sought in other than economic factors, although this does not mean that they have no significance. Economic factors - primarily the employment situation - perhaps have a certain trigger» effect: the migratory pressure caused by non-economic factors is released as soon as economic factors lose their significance as "preventative» hurdles. This can also explain why non-economic factors nearly always surface in individual level studies as the most important causes for return.

\section{Individual approach}

Migration on an individual level can be seen as one behavioral alternative open to an individual in a situation where he experiences his welfare to be indequate. When examining migration on this level, one must analyze which sub-factors offer only a partial satisfaction of needs, and under which circumstances a move to another location or to another country becomes a feasible alternative. The process leading to a decision to move can be examined as a reciprocating relationship between the personal qualities of an individual and the opportunities provided by his environment. The individual attempts to manipulate this reciprocity to achieve his goals. (Wiman 1975)

Empirical studies have established that motives for migration to Sweden have been financial for most of the migrants. The motives for return have been mostly non-financial (social and self-actualizing). These observations are very predictable, because Sweden has clearly been economically more advanced than Finland and has thus offered better opportunities for material welfare.

The limited role that non-material factors play in migration to Sweden is very understandable, since the move means that most migrants will be entering an unfamiliar social, linguistic and cultural environment; this means specifically that possibilities for social interaction and self-fulfilment are weakened.

Of course, there are other than purely financial motives to move to Sweden. In such cases, an individual naturally feels that his chances of satisfying his needs would be greater in Sweden than in Finland. For instance, education can be a reason for migration when one cannot obtain a degree in a given field in Finland, or if it is difficult to enter an institute of higher learning. At the same time it is possible to improve language skills, increase self-knowledge and gain experiences. Personal reasons for migrations may have to do with a desire to leave relationships that have become difficult or an environment associated with the difficulties.

Most migrants seem to plan to return as early as the time they move abroad. Often the return is delayed or not carried out at all, depending on opportunities in the former and current country of residence. Thinking about return becomes timely generally when great changes take place in the life of the family or the individual, such as unemployment, disintegration of the family, children beginning school, retirement, etc.

A decision to return means that an individual feels his opportunities to satisfy his needs in the current country of residence are less adequate than in his old home country. He must thus calculate that he will "gain» more than »lose» when returning. The changes in the circumstances are thus not necessarily the actual reasons for the move, unless they are combined with an actual reduction in opportunities to satisfy one's needs when compared to the opportunities offered by the home country. 
Accordingly, unemployment is likely to cause return migration only in the event an individual calculates his opportunities for employment to be much better in his home country than in his current domicile. If, however, he estimates that opportunities for employment in the home country are bad or worse, but returns anyway, then unemployment acts as a ntrigger" (intervening variable) instead of being the real cause. The individual thus estimates that he will benefit by returning, even if he were not to get work. He may think, for instance, that "it is better to be unemployed at home than in a foreign country". The cause for return then is not unemployment but would rather be connected to social and selffulfilment factors.

The above-mentioned factors would indicate that the criterion for determining the cause of migration could be whether an individual can increase his welfare through migration, as far as a given factor is concerned. Cause for migration might thus be seen as factors in terms of which an individual would consider benefiting.

Financial factors are generally not causes for return, unless the economic opportunities in the countries of departure and arrival essentially change. On the contrary, they often decisively prevent the return, in cases where emigration originally took place for financial reasons. The decision to return is not made, then, as long as the situation that causes emigration in the first place still continues or is believed to continue, assuming that the corresponding situation in the current country does not change for the worse. This depends also on the resources of the individual, which may have increased with time, perhaps because of education. Resources dictate how an individual can compete for the scarce opportunities provided by the environment.

As far as non-material factors are concerned, returnees generally "gain" when they return to their own linguistic and cultural environment and possibly even to their former social framework. A significant intervening variable is, however, how long an individual has remained in the foreign country, i.e., whether these linguistic, cultural and social ties have decisively dissolved during his absence, and how many ties have been formed in the foreign country. It is fairly selfevident, that the longer one has stayed in a foreign land, the less likely he is to return.

One can justifiably assume that reasons for return from Sweden to Finland are based primarily on non-material factors as long as Sweden remains far economically advanced in terms of employment opportunities and salary levels. (The immigrants' economic opportunities may, of course, be poorer than those of the indigenous population.) Given economic factors, such as unemployment, at best trigger the migration; in other words, migration pressure that has its roots in non-material causes can be released, since economic factors lose their significance as preventative factors. It is obvious that a returnee cannot expect to gain anything financially if employment opportunities at home are poorer. If the return takes place in such circumstances, actual reasons must be non-material.

It must be assumed, then, that factors that are social in nature or are related to self-fulfilment are the decisive reasons for return migration, since adjusting to a foreign linguistic and cultural environment is a long-time process, although it varies greatly depending on the resources of the individual. From the beginning, many expect their stay in the foreign country to be temporary, and make no active effort to adjust to the new environment. Rationales for return decrease, however, the longer one stays in the foreign country.

\section{Some empirical results}

\section{The development of migration between Finland and Sweden}

Migration has had a significant effect on population growth in Finland. Approximately 600000 persons have moved from Finland to foreign countries 
$\mathrm{F}$ i g u r e 2. Finnish citizens who moved from Finland to Sweden and from Sweden to Finland in 1946-1983 (according to Swedish statistics)

Thousand



since World War II, and nearly one-half of them have returned. Since the war Finland has lost more than 300000 inhabitants to emigration - a figure that presents over $6 \%$ of Finland's current population. Eighty percent of the emigration has been to Sweden, and a good $70 \%$ of the return migration has been from Sweden.

There are only two periods when the return migration from Sweden has been greater than migration to Sweden. Finland experienced gains for the first time in 1971-74. Another period started in 1981 and continues to the present. During 1981-83, nearly 32000 people returned to Finland, while fewer than 16000 persons moved to Sweden. In 1982-83, migration to Sweden was at its lowest rate since the war.

\section{Motives for return}

The earlier studies have indicated that the motives for return migration are more diverse than the motives for emigration. This may also be the reason for the fact that the bases for classification differ noticeably from each other, which make it difficult to compare the results of studies. However, the common feature in different survey studies has been the fact that the motives for return have been almost completely non-economic. It has also been noted with reference to Lee's push-and-pull theory, that pull-factors are dominant in return migration, whereas push factors are of primary significance in emigration (e.g. Herberts 1977).

In the study made in the Institute of Migration (Korkiasaari 1983) the motives for return were examined by presenting the respondents with 15 alternative motives and by requesting them to mention the importance of each of them and to list the most important motive separately. The results indicate that the most important motives for return for those who returned in 1980-81 have been non-economic, for only approximately $10-15 \%$ (depending on interpretation) considered an economic factor the most important motive of return.

Comparing the motives for return with the results of earlier studies is difficult. The most comparable study is done by Heikkinen (1974). In other studies, the formulation and classification of questions as well as the research population are so different as to make comparison actually misleading. For that reason, only Heikkinen's study has been used for comparison. 
It seems that the significance of the weakened employment situation in Sweden as a motive has increased somewhat and that the significance of the employment situation in Finland as a "pulling" factor decreased, all of which is predictable in consideration of the developing employment situation in both countries. The greatest change has taken place in motives related to concern for children's future and to language difficulties. These changes are very clearly associated with changes that have taken place in the age, marital status and education structure of the returnees.

Those included in Heikkinen's study returned during a period when children and married people played a minor role among the migrants. These groups increased in significance afterwards, but decreased again after 1974. At the end of 1970 's and the beginning of the 1980's the proportion of people with families began to increase strongly again. Reduction in language difficulties, on the other hand, reflects a rapid increase in the educational level of migrants.

Motive for return

Unemployment or uncertain employment situation in Sweden

Narrowing in differences in living standards

Improved employment situation in Finland or obtaining a job

Language difficulties

Concern for children's future/education

Homesickness or not liking Sweden

Family, friendship or private life

Beginning studies or military service in Finland

Temporary stay or achieving goals in Sweden

Other reasons

$\begin{array}{cc}\begin{array}{c}\text { Returned in } \\ 1980-81 \\ \text { (Korkiasaari) }\end{array} & \begin{array}{c}\text { Returned in } \\ 1968-71 \\ \text { (Heikkinen) }\end{array} \\ 6 & 3 \\ 2 & 2 \\ 7 & 12 \\ 2 & 7 \\ 17 & 4 \\ 18 & 22 \\ 16 & 21 \\ 15 & 15 \\ 9 & 4 \\ 8 & 10 \\ 100 & 100 \\ (1875) & (946)\end{array}$

The current return migration resembles in many ways the 1971-74 return migration, when Finland for the first time experienced migration gains. Essential changes have taken place, however. The return migration of ten years ago was largely a counter-wave caused by the great emigration wave of the previous years. Thus a considerable number of people with families moved to Sweden, and this was reflected in the great number of people with families returning.

The return migration of recent years cannot be considered a similar counter-reaction to emigration, for the time span since the returnees migrated to Sweden was very long. Not as many people with families as earlier moved to Sweden in the 1970 's. However, a good number of the current returnees are people with families. This indicates that a greater number of them have established a family while in Sweden than was the case earlier. Thus, more children who were born in Sweden are also included.

The study indicated that providing for the children's future was one of the most important motives for return. It is obvious that most parents begin to consider return at the latest when the children approach school age, since the children's schooling in Sweden and general Swedization can later be decisive obstacles to return. On the other hand, it is likely that the parents' homesickness is often as decisive or even more decisive a motive for return as concern for the children's future, although it is not always given as the most important reason in responses to questionnaires. Perhaps children's approaching school age becomes the "triggering" factor. In part, the responses may also reflect the lively 
discussion concerning children's linguistic development and schooling that has been going in Sweden, and for this reason the parents have become increasingly aware of and concerned about these matters.

\section{Return migrant types}

The earlier studies have generally divided migrants by most significant motives into different migrant types. Types that are based solely on motives of migration do not explain the kinds of characteristics these types have per se. Thus various attempts have been made to analyze these characteristics, generally one at a time, by examining the correlations between the motives of migrations and the demographic characteristics of the migrants through cross-tabulations, for example. This way a very satisfactory image of the migrant types can be obtained. It will, however, be uni-dimensional, since the different characteristics fit singly into the general types and the total image takes shape primarily as a result of intuitive conclusions. Migrant types which simultaneously include several characteristics have rarely been formed.

One of the special features in my study was the formation of return migrant types through cluster analysis. Unlike previous studies, several migrant characteristics were taken into account simultaneously. The analysis included 19 variables: age, education, family size, stay in Sweden and 15 different motives for return. As a result of this analysis, six basic types were formed. The types were identified by using following names: 1) highly educated, 2) older people with families, 3) younger people with families, 4) students, 5) younger nonadapters and 6) older nonadapters.

The following summary can be made of the characteristics of the return migrant types:

1) Highly educated (11\% of returnees, including family members)

This group had a very high level of formal education (university). The average age was about 30 years, and over one-half were married or in a common-law marriage. The size of the family averaged two persons. The average stay in Sweden was three years, and the most important reason for return was the achievement of some goal in Sweden (generally completion of studies, development of language skills or the end of temporary employment).

2) Older people with families (26\%)

These people were, by designation, people with families; the size of the household averaged over four persons. The group was the second oldest in terms of average age. As for the educational level, the group was lowest, for most had acquired only a basic education (elementary school). The stay in Sweden, on the other hand, had been the longest, on the average nine years. Nearly two thirds $(61 \%)$ considered providing for children's future the most important motive for return, but very important additional motives were also homesickness, not liking Sweden, better opportunities for employment and housing in Finland, as well as narrowing of the differences in living standards, and also to some extent, the uncertain employment situation in Sweden and language difficulties.

3) Younger people with families (24\%)

This group was younger than the previous groups, and the family size averaged three persons. The educational level was clearly higher than in the previous group, for approximately two-thirds had a middle-level education (most often vocational education). They had averaged seven years in Sweden, or the second longest time. The most important motive for return was the children's future $(56 \%)$. Other important reasons were, primarily, homesickness and the improved employment situation in Finland. However, the "pull factors" in 
Finland had influenced this group clearly less than was the case with the older people with families.

4) Students (13\%)

Students were the youngest age group and almost all unmarried, with an average household of one person. This group was the only one with more women than men. Over two-thirds had had an upper middle-level education, i.e., had graduated from the high school. The stay in Sweden was the shortest, one-and-a-half years on the average. The most important motive of return was the beginning of studies or military service in Finland or achievement of goal in Sweden (e.g. obtaining language skills and savings).

5) Younger nonadapters ( $16 \%$ )

This group was the second youngest, and included more than an average number of men. The greatest number were unmarried, and the average size of a household one person. The greatest share had a basic or lower middle-level education. Stay in Sweden was the second shortest: two-and-a-half years on the average. The emphasized motives of return were various factors that indicated "nonadaptability", i.e., not liking Sweden, homesickness, family reasons, private life difficulties, unemployment and language difficulties.

6) Older nonadapters (10\%)

This group was the oldest and included a great number of men as well as divorced and widowed persons, with an average family size of 1-2 persons. The educational level was very low, approximately the same as among the older people with families. The stay in Sweden was divided very evenly: a number had been in Sweden only a short time, and a number for a very long time. The average stay was seven years. The motives for return were the same as among the younger nonadapters: homesickness, not liking Sweden, private life problems, family relations, unemployment and language difficulties.

Based on the above it is obvious that groups clearly differ from one another and are realistic in nature. There are no comparisons available with earlier studies, since corresponding (empirical) migrant types were not formed earlier.

\section{Conclusions}

Migration from Finland to Sweden has generally followed economic development in Sweden to the degree that during boom migration has increased, and during recession has correspondingly decreased. On an individual level, unemployment and better salaries in Sweden have been the dominant motives.

To an extent, economic factors are also reflected in return migration. They are not of primary importance, however, but often a type of a striggering" factor, which makes it possible to release the migratory pressure which has been caused by non-economic factors. Economic factors become actual causes only if a migrant believes he or she will gain economic advantages when returning to the home country. Aside from individual exceptions, this kind of a situation is possible only when the economic opportunities in Sweden, primarily the employment situation and the salary levels, become worse than the corresponding opportunities in Finland.

Thus far, economic factors have been obstacles to return rather than causes. The weakening economic situation in Sweden and narrowing differences in living standard between the countries has generally meant that economic factors have lost their significance as obstacles to return. 


\section{References}

Heikkinen, Sirkka-Liisa. (1974). Ruotsista palanneet. Työvoimaministeriön suunnitteluosasto, siirtolaisuustutkimuksia n:o 5, Helsinki.

Herberts, Kjell. (1977). Borta bra men hemma best?. En studie av återflyttare i Närpes. Svenska Litteratursällskapets i Finland. Forskningsrapporter n:o 28, Åbo.

Hietala, Kari. (1980). Muuttoliike ja epätäydelliset työvoimamarkkinat. Työvoimaministeriön suunnitteluosasto, siirtolaisuustutkimuksia n:o 16, Helsinki.

Korkiasaari, Jouni. (1983). Ruotsista Suomeen vuosina 1980-81 palanneet. Siirtolaisuustutkimuksia A 9. Siirtolaisuusinstituutti, Turku.

Siirtolaisasiain neuvottelukunnan mietintö VII. (1982). Paluumuutto. Komiteanmietintö 1982: 14. Valtion Painatuskeskus, Helsinki.

Työvoimakatsaus - Labor Reports. (1982). No. 1-2. Työvoimaministeriö, Helsinki.

Wiman, Ronald. (1975). Työvoiman kansainvälisen muuttoliikkeen mekanismi. Elinkeinoelämän tutkimuslaitos (ETLA), sarja B: 9, Helsinki. 